Article submitted to Cultural Sociology March 2006

Accepted December 2006

Accomplishing journalism: towards a revived sociology of a media occupation ${ }^{1}$

Roger Dickinson

Department of Media \& Communication

University of Leicester

Attenborough Building

University Road

LE1 7RH

United Kingdom

Pre-publication version

Not for quotation without the permission of the author 


\section{Accomplishing journalism: towards a revived sociology of a media occupation ${ }^{2}$}

\section{Introduction}

Journalists sometimes make mistakes. Sometimes these are newsworthy. ${ }^{3}$ Sometimes they attract complaints and corrections are published ${ }^{4}$. Occasionally, they become the subject of dispute and public controversy. ${ }^{5}$ And sometimes journalists deliberately mislead readers, listeners or viewers (including, sometimes, their colleagues) by inventing stories or plagiarizing. In extreme cases delinquent journalists are exposed and their careers end abruptly. ${ }^{6}$

How does this happen? How frequently? Under what conditions? How is a mistake in news work defined and how do journalists and news organizations prevent them? ${ }^{7}$ Sociologists of the media have been surprisingly incurious about these and certain other aspects of journalists' work. In this article I suggest a reason for this and, borrowing a theoretical approach from the sociology of work and occupations, I outline a case for a revived sociology of media work and for renewed attention to journalism as an occupational practice. This will not only help us understand journalists' mistakes, but will also give us a more rounded sociological account of how journalists do journalistic work. Mistakes and misconduct are reminders that journalists are social actors whose behaviour does not always conform to the professional codes, normative frameworks, organizational constraints and source pressures that media sociologists have identified as powerfully determinant. They also draw our attention to one of the core problems in sociology - how social control is defined and maintained in specific social contexts. 
The revival I am proposing is needed because the global news industry is undergoing rapid change. Journalists today reportedly face increasing pressures at work and insider accounts point to these as part of the explanation for delinquency (Dyke, 2004; Blair, 2004). When journalists themselves begin to express concern about the quality and reliability of news output from 24-hour, multi-media newsrooms ${ }^{8}$ the need is perhaps all the greater for adequately theorised sociological research that can give us a more complete understanding of journalists' motivations and how these shape what they do at work and the ways they do it. While insider accounts provide valuable insights, we need empirical research to support sociological analysis that can evaluate their claims. Journalism continues to flourish despite the challenges it faces from critics within the occupation (e.g. Lloyd, 2004), from governments (see Gans, 2003), from academics, and from the changing conditions in which it is conducted. This is so at least partly because, as Zelizer points out, journalism's variety of form, practice, its use of technologies of collection and presentation, and its modes of address are increasing (Zelizer, 2004). The evolving practices of journalism demand closer academic attention than they have received in recent years.

There is also a rather more profound reason to be curious about how contemporary journalists do their jobs. No doubt for reasons of occupational self-interest, but perhaps also for reasons of loyalty, journalists themselves report only the most extreme examples of their colleagues' misconduct and it is unusual for news organizations to correct their errors or to examine them in detail. When they do allow themselves to reflect publicly on mistakes and malpractice journalists are apt to be philosophical. According to one account, 'regular doses of hype, sloppy reporting and uncorrected mistakes' (Marr, 2004: xv) are to be regarded as part of the price of press 
freedom. If this view is as widespread among journalists as this writer implies, then there is still much fertile sociological territory to be charted in their work. Where the boundaries of acceptable and competent practice lie, how these vary within and between media, and how practitioners learn to work within these are surely areas requiring urgent sociological attention. Mistakes occur in every sphere of employment, but journalists' mistakes are of particular interest because of these workers' role in the distribution of knowledge.

In what follows I offer a synoptic overview of the research literature on news production to locate the empirical refocusing I am proposing. I suggest that over the past 50 years the product of journalists' work and the structural, organizational and external forces that help to shape it have been subject to rather closer sociological scrutiny than have journalists themselves, and that there remains considerable scope for research into the occupation. While they are subject to day-to-day influences that help to shape all occupations, journalists are also subject to some that are distinctive and constitutive of journalism itself.

I argue that a theoretical approach long abandoned by sociologists of the media and currently less fashionable among sociologists of work offers some useful points of departure for fresh research in this area. Cottle (2000; 2003a) has called for a 'second wave' of empirical work on the production of news in the present era of change. I suggest where research effort could be directed and describe some theoretical tools that will help us understand better the ways journalists operate in the changing production environment. 


\section{The sociology of news producers, organizations and occupations}

As Zelizer notes, sociology has long been the 'background setting’ for scholarship on journalism (2004: 45) as it has in the study of media production generally, but reviews of research show that its role and emphasis has shifted over time. Boyd-Barrett, (1995) and Cottle, (2003a), for example, show that although the earliest studies of news saw the sociology of journalists as key to their analysis, by the end of the 1970s accounts of news room practice had veered away from the sociology of the news worker. Subsequent research has charted the evolution of the occupation, its cultural and historical shaping, and the changing characteristics of those doing the job, but the sociology of journalists' work has largely been neglected. A survey of previous research on news production will help to show what I mean by this.

In one of the earliest studies, Breed (1955) queried how journalists were made to conform to the editorial policies of their employing organizations. Breed's functionalist account showed that their conformity was the result, not of managerial coercion, but of their colleagues' expectations and a strong sense of group attachment.

Further evidence of this sort came from research testing White's conclusion that news selection depended on the idiosyncrasies of individual journalists (White, 1950). Comparing intake editors in different newspapers Gieber (1964) found little variation between journalists' judgements about newsworthiness. This implied a marked rigidity in production routines. The conclusion was supported by Sigelman (1973) 
who found a striking stability in the news worker's environment. Journalists were largely conformist, complying with organizational goals to minimize conflict.

Tunstall's (1971) functionalist study of specialist correspondents followed Breed by examining reference groups and role expectations but went further to explore journalists' relations with their sources, their colleagues in competing organizations, the goals of their employing organizations, and the wider status hierarchy of specialist journalism. One conclusion was that for it to be manageable, much of news work must be routinized, leading journalists to conform to standardized patterns of reporting and writing.

Using a symbolic interactionist framework Tuchman (1972, 1973, 1978) came to much the same conclusion about American television and newspaper journalists yet her work represents a profound shift in research on news at this point, away from functionalism and organizational analysis, towards an interest in the social construction of news and the making of meaning. Emerging at the height of anti-war radicalism in the US and a resurgence of critical media research, Tuchman saw the social organization of news work as facilitating the mediation of society's dominant ideas; entailing the routinized collaboration between news organizations and news sources to create and impose dominant meanings. Molotch \& Lester's research reinforced this view, seeing news 'promoters' (sources), news 'assemblers' (news workers) and news 'consumers' (audiences) in a collective process of social construction. (Molotch \& Lester, 1974). 
As Tuchman notes, the common factor in a string of studies during the 1970s in Britain and the US (e.g. Altheide, 1976; Fishman, 1980; Gans, 1979; Golding and Elliott, 1979; Schlesinger, 1978) was the notion that news was 'made' rather than 'found', the prime determinant being the 'social and organizational' context of news work (2003: 80). Journalists were central to the process of meaning creation, but were subject to inflexible production codes and conventions and to underlying economic imperatives. By the 1980s newsroom research was thus engaged in a social critique of the media rather than an understanding of the occupation of journalism. The prevailing view was of journalism as a set of roles learned on the job, followed routinely and, it seemed, largely unquestioningly. Research attention was drawn increasingly to the constraining influences on news work and away from the news workers themselves. Where workers were the focus, media scholars tended not to offer accounts in terms that sociologists of occupations would recognise. Yet, as I argue shortly, thinking about journalism as an occupational practice continues to have important theoretical benefits.

\section{Recent research on media production}

The dominant approach to studying media production has developed in several ways. One has been to examine the constraints that media organizations place on their employees in order to improve managerial efficiency and increase competitiveness. Born, for example, has shown how the BBC exerts particular constraints on those producing programmes that are characteristic of that organization, stemming from its institutional norms, its managerial and organizational ethos and its position in British culture (Born, 2004). Schlesinger's study of BBC news, in research conducted some 
20 years earlier, found a similar set of constraining influences, if differently configured (Schlesinger, 1978).

Other research has paid closer attention to constraints from outside media institutions. The suppliers of news have been seen as especially powerful. Media-source relationships have received a great deal of attention from, in the main British, media sociologists (e.g. Miller, 1993; Schlesinger and Tumber, 1994; Palmer, 2000; Manning, 2001; contributors to Cottle, 2003b), although the study widely regarded as seminal in this genre is Canadian (Ericson et al, 1989).

Researchers who have tightened their focus on occupational practices in media workplaces have pursued a course of enquiry that seems almost to have abandoned sociology altogether. By the 1990s British work was giving prominence to producers’ accounts in explanations of how media content is produced instead of applying more abstract, sociological models of analysis. Boyd-Barrett (1995) notes an obvious difference between Tunstall's study of journalists published in 1971 (Tunstall, 1971) and his work on television producers published around 20 years later (Tunstall, 1993). In place of a sociological analysis of an occupation Tunstall offers detailed descriptions of working practices and careers, a trend that continues in his later work (Tunstall, 1996, 2001).

Describing this more 'grounded' approach Boyd-Barrett cites as a key example Morrison \& Tumber's interviews with British journalists covering the Falklands War, explaining the creation of news in terms of 'operatives within a system rather than operators of a system’ (Morrison \& Tumber, 1988: x). This echoed claims made by 
Ericson and colleagues in an earlier report of the Canadian study just mentioned (Ericson et al, 1987) who similarly dissented from the dominant view of the journalist as automaton. The news industry as a whole, the organizations journalists work for, and the individuals and institutions that supply them with news create the structure within which journalists must act, but the Canadian researchers found that journalists’ own motivations and aspirations were highly influential. Production processes did not go unquestioned or patterns of reporting and presentation uncontested. The newsroom was more a place of conflict than conformity. Bantz's organizational analysis pointed to the same conclusion (Bantz, 1985). While Sigelman's rule-following and Tuchman's and Tunstall's routinization were evident, disputes and arguments over the way journalism should be done were an intrinsic part of the job. The level of conflict and contradiction varied between media, but the fact that conflict was not only observable but also common across media suggested that the conclusions from research that saw journalists as unwitting cogs in an ideological machine needed modification. News content might well be patterned, but it was the daily work of journalists to negotiate with each other over the pattern's main features. Ericson and his colleagues and Bantz were able only to outline these aspects of news work, but their research indicated a complexity requiring a more finely nuanced account of journalistic practice.

At first sight, the grounded approach seems to offer this. The benefits of Morrison \& Tumber's work, for example, lie in the level of detail they present in their descriptions of working practices. Tumber's account of the experiences of 'embedded' journalists during the war in Iraq continues with the approach, providing a history of the events leading to the organization of war coverage, and, pursuing the 
theme of source-media relationships, focussing on media-military and mediagovernment interaction (Tumber \& Palmer, 2004). Cottle’s ethnography of British regional television news uncovered the determining influence on 'news discourse' of ‘contexts of production', news formats, and a news organization's idea of its target audience (Cottle, 1993, 1999). Eliasoph’s and Jacobs’s studies of US local television news stations found similar interrelationships between elements in the process, news workers producing news through the practice of 'narrative emplotment' (Jacobs's term) informed by their interpretations of an event's newsworthiness and the ways it might be made meaningful (Eliasoph, 1988; Jacobs, 1996). This interrelationship has been demonstrated in studies of news aimed at specific audience segments (Forde, 2003; Matthews, 2003). But while it complements the numerous practitioner accounts (e.g. Watkins, 2000; Marr, 2004; Snow, 2004) that offer vivid impressions of the craft and business of journalism, this research has surprisingly little to say about news workers' lived experiences. While an important part of these analyses recovers a sense of news worker's agency, media researchers seem reluctant to balance their accounts of the constraining effects of contextual, organizational, economic, source, or formal regulatory factors with sociological analyses of journalists' daily judgements about what is required in their jobs, what the production of acceptable journalism entails, or how they learn to accomplish it. One gets little sense from this research of the negotiated, collective behaviour of human actors in social settings.

While further insights are available from accounts of the history and evolution of journalism as a discursive form (Chalaby, 1998) and as an emerging occupation in specific national and cultural contexts (e.g. Palmer, 2003), these too leave our understanding of the daily practice of journalism incomplete. Even what Zelizer calls 
‘studies of journalism as people’ (e.g. Splichal \& Sparks, 1994; Weaver \& Wilhoit, 1996, cited in Zelizer, 2004) and studies that explore the evolution of journalism in different parts of the world (e.g. Hallin, 1994; Weaver, 1998; Mancini, 2000; Waisbord, 2000) leave our understanding of daily journalistic practice unduly shadowy. What they do show is that there are many journalisms. The forms they take, the principles that guide them and the practices followed are shaped by their historical, cultural, economic, and political contexts (see de burgh, 2005). But whatever its merits this work reveals too little about the practice of journalism as a social act, too little of the ways journalists learn to perform their occupational roles. Ericson et al (1987) found that conflict and the need to resolve it helped journalists become competent. Media sociology has yet to deepen our understanding either of how this comes about, or how it might be changing.

I am not arguing for a revived sociology of journalism, for that is clearly alive and well in work located in a variety of vibrant sociological traditions, some of the more illuminating among them coming from outside what has become the mainstream of media sociology. Recent discussions by US media sociologists of the media-saturated nature of contemporary society in which journalism becomes ever more simplified and anodyne (Gitlin, 2002), the growing tendency towards cynicism and 'infotainment' in journalism (Schudson, 2003) and accounts of the gradual 'disempowerment' of US journalists (Gans, 2003) are evidence of the continued significance of journalism in contemporary sociology. But these writers do not offer the depth of analysis that I believe is also urgently required. For example, Gans's book is written with an emphasis on the determining influence of social structure and, though valuable in charting the reasons for the increasingly marginalised and 
weakened role of contemporary journalism, it assumes a uniformity at the level of the individual news worker and his/her responses to the changes that have come about. Once again, journalists appear to be relatively powerless followers of routine and custom.

At another level research influenced by Bourdieu (Benson, 2004a; 2004b; Benson \& Neveu, 2005) is clearly important as a way of refocusing attention on the dynamics and relations in what Benson describes as the 'interorganizational, professional, social and indeed cultural space within which journalists situate or orient their action and interaction.' (Benson, 2004b: 311). The concept of the journalistic field provides a way to explain how and why different news media practices take the form that they do in different cultural contexts, and helps to account for their similarities and differences. But, although the directions for future research that this approach offers may help to improve our understanding of the role of media relative to other social institutions, they will at the same time continue to overlook the importance of journalist agency in the production of news precisely because of the emphasis they place on processes occurring at an institutional level. Viewed from Benson's mezzo perspective what contemporary journalism is and how journalists do it, remain elusive.

Related to Benson's culturalist approach are studies taking a closer view of journalists' role in contemporary culture. Hannerz’s study of foreign correspondents (Hannerz, 2004) begins to sketch in some of the detail of practice I suggest should be central to our understanding of journalists, although his concern with the process of 'cultural flows' is rather different, being concerned once again with the products of 
news work - the meanings and interpretations of journalists 'writing home' - and is realised theoretically at a much broader level of analysis. In the field of cultural social studies, work by two authors stands out for its emphasis on journalists' practices. Eliasoph's study of political apathy in suburban America shows how local news reporters' working routines produce news that helps to push political activism to the margins of daily life (Eliasoph, 1998). Similarly, Gamson's studies of celebrity culture (Gamson, 1994) and television talk shows (Gamson, 1996) contain illuminating depictions of journalists’ practices in detailed analyses of contemporary US culture. As Zelizer argues, thinking of journalism (and news - Allen, 1999) as culture offers some enticing prospects for research that can enrich our understanding of journalism's role in the daily creation and reproduction of meaning. In doing this these studies go some way to return our attention to journalists’ practices, but these are not their main focus and remain marginal to them theoretically.

Instead of a sociology of journalism, then, my call is for a renewed acquaintance with the sociology of journalists via the study of them as members of a distinctive occupational category engaged in a distinctive, and changing, form of labour.

\section{Media industries, employment practices and the occupational perspective}

This is important because the introduction of new production technologies, the need for cost cutting and 'downsizing' in response to changing market conditions, and the intensive competition for declining audiences have created new challenges for journalists (MacGregor, 1997; Cottle, 2003a; Franklin, 2003). As Cottle (2000) notes, this evolving production context calls for fresh exploration and analysis. The impact 
of industry changes on news output have been the subject of debate in media sociology for some time (e.g. Franklin; 1997; McNair, 1998, 2000). Neither side of the 'dumbing down' debate makes much of the working practices of journalists, tending instead to examine the products of their work, but research on journalists' employment conditions suggests that labour-saving production technologies, multiskilling and the consequently reduced opportunities for team working have a 'deskilling' effect (Bromley, 1997; see also Cottle, 1999; Ursell, 2003). But if the new conditions are threatening journalistic standards and the quality of news output, whether the focus is on the product of journalism or the changing organizational constraints under which journalists work, their motivations and responses remain obscure.

Insider accounts of delinquent journalists remind us that news work involves social actors whose actions can be understood in terms of their status as employees. Some conjure up images of the hard-pressed reporter 'out of control', the social order of the newsroom disrupted. ${ }^{9}$ But in what ways are the working practices of delinquent journalists unconventional or disorderly? What is orderly journalism and how do journalists know when they are practicing it? How is journalism managed in the increasingly pressured conditions of the newsroom? Accounts of delinquency question the efficiency of workplace management systems and editorial processes and these certainly invite scrutiny, but to keep the journalist as the focus of study it may be most helpful to see him or her as a member of a collective, socially bound in the workplace, sharing understandings of what is required and how things should be done. 
Studies of crime commonly take this perspective, showing how informal social controls can lose their force in communities where members judge deviance to be widespread. Under certain conditions a shift in collective definitions of what constitutes acceptable behaviour can lower moral standards. Moynihan (1993, cited in Welch et al, 2005: 24) describes this process of ‘normative erosion' as 'defining deviancy down'. Such a process may be observable in workplaces where deviance becomes acceptable among employees to ensure tasks are completed. If the news is indeed 'dumbing down' the defining down of deviance in journalism may well be a factor in the process. This and the boundary between 'acceptable' and 'unacceptable' (and thus visible) deviance suggest potentially fruitful areas of empirical enquiry.

As I have noted already, studies of news over the past thirty years or so have made us accustomed to thinking of journalism as a part of a process of manufacture (Cohen \& Young, 1981; Schudson, 2005; Tuchman, 2003), but we should not forget that such processes involve work; news workers must learn how to do this work in such a way that they are deemed worthy of the title 'journalist', that they can act 'professionally', and that their work can be described as ‘journalism'. Ericson et al (1987) showed how the journalists in their study learned a 'vocabulary of precedents', accumulating a stock of knowledge from which to draw. We need to return to a research approach that can help us to better understand this process and learn, with reference to the wider occupational community and in changing working conditions and employment contexts, how ordinary journalists, working together with their colleagues and sources, accomplish journalism. ${ }^{10}$ How do journalists learn their working routines; how do they learn to 'do journalism' in a way that is acceptable to their employers and their colleagues; how are they supervised; which personal attributes and skills are 
likely to secure them employment and keep them in it; what impact do errors have on careers? Answers to these questions will bring insight not only into how, and the circumstances under which, given publicly acknowledged errors come about, but also how frequently we might expect them to occur. This is more important than simply seeking to confirm that errors are 'normal' in journalistic work. Accompanying a concern with the formal regulation of organizations, a revived sociology of journalists will turn attention to the less formal, everyday regulation of media workers. Although media sociologists have neglected these questions, they are worth returning to now because of the news industry changes noted above. ${ }^{11}$

Reviving our interest in journalism as an occupation has distinct advantages. ${ }^{12}$ Despite the huge variations in the role across and within media and the widening scope of the term 'journalist', journalists do seem to have a sense of shared identity. This is important because industrial sociologists have shown that the sharing of an occupational identity can lead to the recognition of shared economic interests, and thus form the foundation for collective action. In some occupations this may be manifest in trade unionism; in others it may focus on the fostering of public recognition for an occupation's specialized knowledge, forming the basis for control over entry into that occupation, and, in turn, pay. Freidson (1986) distinguishes between 'administrative' and 'occupational' principles within organizations. Organizations can be characterized by the extent to which the control of work lies mainly with administrators or mainly with members of an occupation working within them. Studies in the sociology of work and organizations have explored how the occupational principle has been affected by social, technological and economic changes in a number of settings (see, for example, Ackroyd et al, 2005) and have 
shown that the occupational principle has shaped work relations and employee practices in a variety of ways and with varying degrees of success for the occupations in question.

If the changes identified by Bromley (1997), Franklin (1997), MacGregor (1997) and Gans (2003) suggest that journalists are in a weakened position, implying a decline of the occupational principle as it applies to them (in contrast to the situation encountered by media sociologists in the 1970s), recent evidence from the UK suggests that a counter trend is discernible. Gall shows that, in response to changes in government employment legislation, after a decade or so of retreat, trade unionism is re-establishing itself among journalists in the local and regional press, with consequences for workplace organization, albeit it of a generally non-militant nature (Gall, 2002; 2005). Strong evidence of a collective journalistic occupational identity also emerged when the publication of the Hutton report in 2004 triggered public protests by BBC journalists against the perceived 'attack on journalism' (see Tumber \& Palmer, 2004; see note 12 below).

The lens of occupation also enables us to connect a study of practices with the sociology of professions. Traditionally, journalists have been drawn to one or other form of collectivised pursuit - trade unionism or professionalization. Aldridge \& Evetts (2003) argue, intriguingly (see below), that as journalists' working conditions and practices have altered with changing times, in the multi-media, 24-hour, multi- or, perhaps, de-skilled present, this ambivalence is now nearing its end - a claim that invites empirical investigation. 'Occupation' thus helps us to frame some important 
questions about contemporary journalists at work and shows where we might find answers to them.

\section{Towards a revived sociology of media work}

How might this sort of research into media work begin? There are several concepts from much earlier studies of work that will be helpful. I will focus on three: regulation, ethical practice, and occupational socialization, for these seem especially apt in relation to questions of delinquency in journalism, but they also indicate some interesting and potentially fruitful lines of enquiry into media work in general. The approach offers a way of reviving the sociological perspective in the study of media production as a whole.

\section{Regulation}

In a well-known discussion of what he calls the 'symbol' of profession Becker (1970) provides a reason why professionals must have complete autonomy over their work through systems of self-regulation. Autonomy is important, Becker argues, because only those belonging to a profession possess the esoteric knowledge to be able to judge when a colleague has not performed professionally. ${ }^{13}$.

An important respect in which professionals fall short of the professional symbol is that they are 'not as autonomous as the symbol would have us believe' (Becker, 1970 p101). As we have already seen, there is plenty of evidence from research on news production to support this view with regard to journalists. Again, Becker uses the example of medical practitioners, explaining that the wishes of doctors' clients limit 
their freedom because of the need to ensure, for the sake of reputation and continuing relationships with them, that the quality of service they provide is thought to be satisfactory. $^{14}$

Freidson's study of American medical practitioners explored this further (Freidson, 1975). Working in a bureaucratically organized health centre that separated medical practice from the business of fee administration, these doctors were adapting to new ways of group working. Distinguishing between indirect social control of administrative rules and conditions of employment, and direct social control operating less formally, within the professional group, Freidson showed how doctors collaborated to maintain their autonomy (Freidson, 1975: 6-7; 252-259). ${ }^{15}$

The distinction clearly offers some analytical purchase for the study of other occupations, but it seems especially apt as a basis for studying contemporary media work where employment conditions are changing and workers struggle to control the 'professional symbol’ of their occupation.

The question of control over work is a central concern of the sociology of occupations. Recent studies have drawn on Foucault for a framework in which to consider the way the professional ideal can itself act as a control on employee behaviour. The ultimate beneficiary is not the employee but the organization for which s/he works. Thus the discourse of professionalism can be seen as facilitating the introduction of new forms of work organization and systems of employment relations (Fournier, 1999; Casey \& Allen, 2004). This thinking has recently been applied in the analysis of the professional status of journalists (Aldridge \& Evetts, 
2003), suggesting that employees' occupational control has been weakened by changing employment conditions. As a result, these writers argue, the discourse of professionalism is used increasingly in employees' self-conceptions.

What makes Freidson's study of medical practice relevant today is that it offers both a way of thinking about these issues systematically and a model for exploring them empirically. So far we have little data on journalists themselves and their responses to the overarching mechanisms of control that Foucauldian theory suggests are in place, and little data supporting adequately theorised suggestions as to why there might be failures in the systems that are thought to secure them. To understand this better we need data on the features of contemporary media work that cohere into a sense of what it means to act as a 'professional journalist'. Thus, while much has been written on the indirect control of journalistic activity (e.g. McQuail, 1992; 2003) we also need to attend to the direct control operating within professional groups of journalists in specific settings.

Historically in the UK journalists have successfully resisted regulation from outside the occupation. Media institutions are externally controlled at only the broadest, organizational level. The conditions for their operation are the subject of regulation designed to safeguard independence from political interference, prevent unfair competition in the marketplace, protect individual rights and public interests, and so on, but the control of their daily operations and the behaviour of their employees largely remains in their own hands. 
Despite the pressures of the workplace (Cottle, 1999; Aldridge \& Evetts, 2003; Ursell, 2003), journalists continue to set the standards for their professional performance $^{16}$. They are, through the informal mechanisms of social control in the workplace, in direct control of these standards and their application. We know little about the informal side of journalism and public debate is rarely concerned with it. When it is (e.g. at the time of the Hutton Inquiry) the assumption is that this is merely a matter of internal managerial concern.

\section{Ethical practice}

Closely related to the question of regulation is that of ethics. As in any workplace, journalists work in an environment where certain behaviours are thought to be morally appropriate and others less so. Of this we know little beyond press reports and insider exposés of the more extreme cases. How is ethical journalistic behaviour shaped within a media organization? How are breaches of 'normal' practice handled and contained? Here again, earlier sociological theorising suggests a way of thinking about this.

Becker argues that unethical behaviour in a profession is less 'a matter of human frailty' and more an intrinsic feature of its social structure. He finds support for this in Everett Hughes's work on lawyers. Hughes identified what he called the 'moral division of labour' in the world of work, observing that all professions contain 'unethical practitioners'. Those that are unethical do some of the work necessary for the enterprise in which they are engaged; there are quacks and crooked lawyers and their equivalents in every occupation. Hughes's point is not that there are good and bad doctors or lawyers but that the system of their occupation - the way their 
occupation works - depends on the bad ones doing some of the work (Hughes, 1958:71 cited in Becker, 1970:100). The systems in which everyday unethical practice is entrenched remain less than perfectly understood nearly half a century after Hughes’s observations.

The misconduct of 'maverick' or 'undisciplined' journalists raises important questions about the way their actions are understood by other journalists, whether and how they are managed and the degree to which they are recognized, normalized and accommodated in the workplace. If think of journalism as a collective activity involving the kind of shared understandings that Hughes suggests are present in all occupations, we will be in a better position to offer a properly sociological interpretation of journalistic delinquency not only of the kind exhibited by the likes of Jayson Blair but also of the more mundane kind that appears to be routine in some news production contexts - from errors of fact to reporting practices regarded by outsiders as 'unscrupulous', involving breaches of confidentiality or invasions of privacy, sometimes causing controversy and public debate.

\section{Occupational socialization}

In an article on adult socialization Becker makes the point that studies of social organizations of any kind - occupations, workplaces, families, or neighbourhoods are at the same time studies of adult socialization. They help us understand the process of the continual development of the self (Becker, 1970: 299).

The nature of socialization into institutional culture depends on the extent to which members of that institution are able to communicate with one another. In other words, 
an institutional culture can only develop if its members can speak to each other. As Becker suggests, this is important in the process of 'situational adjustment' - a process that people go through whenever they join an organization. To adjust to the new environment people have to learn 'how things are done around here'. This process necessarily entails a number of others.

During the Hutton Inquiry accounts of the BBC news reporter Andrew Gilligan's behaviour made reference to the fact that he was a 'tabloid journalist' newly arrived in a broadcast environment where the rules of balance and impartiality hold sway over the exaggeration, sensation and speculation to which he was allegedly more accustomed. Some of the changes that the BBC's internal post-Hutton inquiry recommended would appear to be based on an assumption that Gilligan's behaviour stemmed from a failure to adjust to his working situation. The BBC's currently promotes a more robust attitude to the training of its staff through the establishment of a 'College of Journalism' to guard against this in the future (Neil, 2004). The role that training takes in this context can also be understood sociologically as assisting in the creation of occupational commitment. Once again we know very little of the routine mechanisms of situational adjustment or commitment to journalism. How does a journalist joining a new organization learn the ropes and find out 'how things are done'? How does he or she adjust to a new newsroom situation? What factors do journalists consider to be valuable in their work and thus contribute to a commitment to their occupation and their job? Much earlier work by Solomon (1970) could guide us towards some answers here. Solomon examined the way individuals in various occupations balance roles in different organizations and as organizations change with self-conceptions formed at earlier stages in their careers. One of his conclusions was 
that an employee's occupational commitment and their self-conception are linked in a number of ways; where the linkage is weak the employee experiences difficulties. In an era of increasing casualization of media work the study of how media organizations nurture adherence to workplace norms and routines should be a source of particular interest for contemporary media sociology.

\section{Conclusion}

In this article I have attempted to outline a direction of enquiry that I believe offers some promise for a much more rounded sociological understanding of media production than we have so far. Prompted by reports of a number of journalistic errors and acts of journalistic delinquency, I began by suggesting that our knowledge of the context in which such phenomena occur is incomplete. Concentrating mainly on the study of news production, I argued that media sociologists have neglected important sociological aspects of media work, and I suggested that change in the media industries and evolving media production contexts require renewed research interest in the media worker. This entails altering the focus of research away from the problem of media power and the construction of meaning, returning to the sociology of journalists in place of the sociology of journalism.

I suggested that it could be helpful to consider media work as resulting from collective behaviour, involving social actors in a process of occupational accomplishment. This process requires members of an occupation to share an understanding of what is needed to get the job done and what is and what is not acceptable practice at work. This does not happen in a vacuum. As I have indicated, 
recent writing in the sociology of work and employment has shown that occupational settings can be thought of as places of constraint and regulation. A similar view, albeit with rather different theoretical underpinnings, was common among media sociologists of the 1970s and 1980s. I have suggested that an empirically grounded understanding of the way members of an occupation act in relation to external and internal regulatory and ethical codes and how they are socialized into their work roles can reveal a great deal about that occupation and the way it is adapting to changing circumstances.

I have chosen the examples of media work in general and journalism in particular to illustrate the benefits of reviving an older sociology of occupations to assist in developing the refocused sociology that I have in mind. In doing this I have sought to draw the attention of my colleagues in two fields. Those who study the media will find a type of sociological approach that is needed the better to understand not only what journalists do, but also media work, its organisation and accomplishment, in general. Those who study the sociology of work will have been alerted to some of the features of media occupations that might be instructive when making the kind of comparisons between occupations called for by Everett Hughes over half a century ago (Hughes, 1994).

\section{References}

Ackroyd, S., Batt, R., Thompson, P. and Tolbert, P. S. (eds) The Oxford handbook of work and organization. Oxford: Oxford University Press.

Aldridge, M. and Evetts, J. (2003) Rethinking the concept of professionalism: the case of journalism. British Journal of Sociology 54 (4) 547-564. 
Allan, S (1999) News culture. Buckingham: Open University Press.

Altheide, D. L. (1976) Creating reality Beverly Hills, CA: Sage Publications.

Bantz, C. R. (1985). News organizations: Conflict as a crafted cultural norm. Communication 8 225-244.

Becker, H. S. (1970) Sociological work. Method and substance New Brunswick, New Jersey: Transaction Books.

Benson, R (2004a) Bringing the sociology of the media back in. Political Communication 21, 275-292

Benson, R (2004b) Why conceptual models and 'big' institutions matter: a response to David Altheide, Nina Eliasoph, William Gamson, and Todd Gitlin. Political Communication 21, 311-314

Benson, R. and Neveu, E. (2005) Introduction: field theory as a work in progress. In Benson, R. and Neveu, E. (eds) (2005) Bourdieu and the journalistic field Cambridge: Polity Press, pp1-28.

Born, G. (2004) Uncertain vision. Birt, Dyke and the reinvention of the BBC London: Secker \& Warberg.

Boyd-Barrett, O. (1995) The analysis of media occupations and professionals. In Boyd-Barrett, $\mathrm{O}$ and Newbold, C (eds) Approaches to media. A reader London: Arnold, pp 270-6.

Bromley, M. (1997) The end of journalism? Changes in workplace practices in the press and broadcasting in the 1990s. In Bromley, M \& O’Malley, T (eds) $A$ Journalism Reader London: Routledge, pp 330-350.

Breed, W. (1955) Social control in the newsroom: a functional analysis. Social Forces 33, $326-55$.

Blair, H. (2001) 'You're only as good as your last job': the Labour process and labour market in the British film industry. Work, Employment and Society 15 (1) 14969.

Blair, H. and Rainnie, A. (2000) Flexible films? Media, Culture and Society 22 (2) 187-204.

Blair, J. (2004) Burning down my master's house: my life at the New York Times Beverly Hills, CA: New Millennium Press.

Casey, R. and Allen, C. (2004). Social housing managers and the performance ethos: towards a 'professional project of the self'. Work, Employment and Society 18(2): $395-412$.

Chalaby, J. K. (1998) The invention of journalism London: Palgrave. 
Cohen, S. and Young, J. (eds) (1981) The manufacture of news. Deviance, social problems and the mass media London: Constable.

Cottle, S. (1993) TV news, urban conflict and the inner city Leicester: Leicester University Press.

Cottle, S. with Ashton, M (1999) From BBC Newsroom to BBC Newscentre: on changing technology and journalist practices. Convergence 5 (3) 22-43.

Cottle, S. (2000) New(s) times: towards a 'second wave' of news ethnography. Communications: the European Journal of Communication Research 25(1): 19-41.

Cottle, S. (2003a) Media organization and production: mapping the field. In Cottle, S (ed) Media organization and production. London: Sage Publications, pp3 24.

Cottle, S. (ed) (2003b) Media organization and production. London: Sage Publications.

Curran, J \& Seaton, J (1997) Power without responsibility. The press, broadcasting and new media in Britain. London: Routledge

de burgh, H. (2005) Making journalists. London: Routledge.

Delano, A. and Henningham, J. (1995) The news breed. British journalism in the 1990s. London: London Institute.

Dex, S., Willis, J., Paterson, R., and Sheppard, E (2000) Freelance workers and contract uncertainty: the effects of contractual changes in the television industry Work, Employment and Society 14 (2) 283-305.

Dingwall, R. (1976) Accomplishing profession. The Sociological Review 24 (2) 33149.

Dyke, G. (2004) Inside story London: Harper Perennial.

Eliasoph, N (1988) Routines and the making of oppositional news. Critical Studies in Mass Communication 5 313-334.

Eliasoph, N (1998) Avoiding Politics: How Americans Produce Apathy in Everyday Life. Cambridge: Cambridge University Press

Ericson, R. V., Baranek, P M, and Chan, J B L. (1987) Visualizing deviance. A study of news organization Milton Keynes: Open University Press

Ericson, R.V., Baranek P.M., and Chan, J. B. L. (1989) Negotiating control: a study of news sources Milton Keynes: Open University Press.

Fishman, M. (1980) Manufacturing news Austin: University of Texas Press. 
Forde, E. (2003). Journalists with a difference: producing music journalism. In Cottle, $\mathrm{S}$ (ed). Media organization and production London, Sage Publications, pp 113-130.

Fournier, V. (1999). The appeal to 'professionalism' as a disciplinary mechanism. The Sociological Review 47(2): 280-307.

Franklin, B. (1997) Newszak and news media London: Arnold.

Franklin, B. (2003) 'A good day to bury bad news'?: Journalists, sources and the packaging of politics. In Cottle, S (ed) News, public relations and power London: Sage Publications, pp $45-62$.

Freidson, E (1986) Professional powers. A study of the institutionalization of formal knowledge. Chicago, Ill: University of Chicago Press.

Freidson, E. (1975). Doctoring together. A study of professional social control Oxford: Elsevier.

Freidson, E. (1962) Dilemmas in the doctor-patient relationship. In Rose, A. M. (ed) Human behaviour and social processes. An interactionist perspective London: Routledge and Kegan Paul.

Gall, G. (1998) The changing relations of production: union derecognition in the UK magazine industry, Industrial Relations Journal 29(2): 151-61.

Gall, G. (2002) The return of the National Union of Journalists to the provincial newspaper industry in Britain? Media, culture and society 24 (5) 673-92.

Gall, G (2005) Back from the brink or still on the margins? The National Union of Journalists in the provincial newspaper industry in Britain. Journalism 6 (4) 422-441

Gamson, J (1994) Claims to fame. Celebrity in contemporary America. Berkley, CA: University of California Press.

Gamson, J (1996) Freaks talk back: tabloid talk shows and sexual nonconformity Chicago, Ill: University of Chicago Press

Gans, H. J. (1979) Deciding what's news New York: Pantheon.

Gans, H. J. (2003) Democracy and the news. Oxford: Oxford University Press.

Gieber, W. (1964) News is what newspapermen make it. In L.A. Dexter \& D Manning White. People, society and mass communications New York, Free Press, pp 173-80.

Gitlin, T. (2002) Media unlimited. How the torrent of images and sounds overwhelms our lives. New York: Owl Books. 
Golding, P. and Elliott, P. (1979) Making the news London: Longman.

Granger, B., Stanworth, J., and Stanworth, C. (1995) Self-employment career dynamics - the case of unemployment push in UK book publishing. Work, Employment and Society 9 (3) 499-516.

Hallin, D. C. (1994) 'We keep America on top of the World'. Television journalism and the public Sphere. London: Routledge.

Hannerz, U. (2004) Foreign news: exploring the world of foreign correspondents Chicago, Ill: University of Chicago Press.

Hughes, E.C. (1994) Work and the self. In E.C. Hughes On work, race and the sociological imagination. Chicago: the University of Chicago Press, pp57-66 (first published in J. Rohrer \& M. Sherif (eds) (1951) Social work at the crossroads New York: Harper, pp313-23.

Hughes, E. C. (1958/1964) Men and their work Glencoe, Ill: Free Press.

Hutton, Lord (2004) Investigation into the circumstances surrounding the death of Dr David Kelly. Available at <http://www.the-hutton-inquiry.org.uk/>

Jacobs, R. (1996) Producing the news, producing the crisis: narrativity, television and news work. Media Culture and Society 18 (3) 373 - 398.

Lloyd, J. (2004) What the media do to our politics. London: Constable \& Robinson

Mancini, P. (2000) Political complexity and alternative models of journalism: the Italian case. In James Curran and Myung-Jin Park (eds) De-Westernizing media studies. London: Routledge, pp 265-278

Manning, P. (2001) News and news sources: a critical introduction London: Sage Publications.

Marr, A. (2004) My trade. A short history of British journalism London, Macmillan.

Matthews, J. (2003) Cultures of production: the making of children's news. In Cottle, S (ed). Media organization and production London, Sage Publications, pp 131-146.

MacGregor, B. (1997) Live, direct and biased? Making television news in the satellite age London: Arnold.

McNair, B. (1998) The Sociology of Journalism London: Arnold.

McNair, B. (2000) Journalism and democracy: an evaluation of the political public sphere London, Routledge. 
McQuail, D. (1992). Media performance. Mass Communication and the Public Interest London, Sage.

McQuail, D. (2003). Media accountability and freedom of publication Oxford, Oxford University Press.

Miller, D. (1993) Official sources and 'primary definition': the case of Northern Ireland. Media, culture and society 15 (3) 385 - 406.

Molotch., H. and Lester, M. (1974) News as purposive behaviour. American Sociological Review 39 101-12.

Morrison, D. M. and Tumber, H. (1988) Journalists at war London: Sage Publications.

Moynihan, D. (1993) 'Defining deviancy down: how we've become accustomed to alarming levels of crime and destructive behaviour. The American Scholar 62, 17-30.

Neil, R (2004) The BBC's journalism after Hutton. The report of the Neil review team Available at: <http://www.bbc.co.uk/info/policies/neil_report.shtml $>$

O’Malley, T. \& Soley, C. (1998) Regulating the press. London: Pluto Press.

Palmer, J. (2000) Spinning into control: news values and source strategies London: Leicester University Press.

Palmer, M. (2003) Parisian newsrooms in the late nineteenth century: how to enter from the agency back office, or inventing news journalism in France. Journalism Studies 4 (4) 479 - 487

Schlesinger, P. and Tumber, H. (1994) Reporting crime: the media politics of criminal justice Oxford: Clarendon Press.

Schlesinger, P. (1978) Putting 'reality' together: BBC news London: Constable.

Schudson, M. (2003) The sociology of news New York: Norton.

Schudson, M. (2005) Four approaches to the sociology of news. In Curran, J. and Gurevitch, M. (eds) Mass media and society $4^{\text {th }}$ edition. London: Arnold, pp $172-197$.

Sigelman, L. (1973) Reporting the news: an organizational analysis. American Journal of Sociology 79 132-51.

Smith, J. (2004) Fifth Report - Safeguarding Patients: Lessons from the Past Proposals for the Future Command Paper Cm 6394. 9 December 2004.

Snow, J. (2004) Shooting history. A personal journey London, Harper Collins. 
Solomon, D. N. (1970) Role and self conception: adaptation and change in occupations. In Shibutani, T (ed) Human nature and collective behaviour. Papers in Honor of Herbert Blumer Englewood Cliffs, NJ: Prentice Hall.

Splichal, S. \& Sparks, C. (1994) Journalists for the 21st Century. Norwood, NJ: Ablex.

Tuchman, G. (2003) The production of news. In Jensen, K. B. (ed) A handbook of media and communication research: qualitative and quantitative methodologies London: Routledge, pp 78 - 90.

Tuchman, G. (1978) Making news: a study in the construction of reality New York: Free Press.

Tuchman, G. (1973) Making news by doing work: routinizing the unexpected. American Journal of Sociology 79 (1) 110 - 31.

Tuchman, G. (1972) Objectivity as strategic ritual: an examination of newsmen's notions of objectivity. American Journal of Sociology 77 (4) 660 - 79.

Tumber, H. and Palmer, J. (2004) Media at war: the Iraq crisis London: Sage Publications.

Tunstall, J. (1971) Journalists at work London: Constable.

Tunstall, J. (1993) Television producers London: Routledge.

Tunstall, J. (1996) Newspaper power: the new national press in Britain Oxford: Oxford University Press.

Tunstall, J (2001) Introduction. In Tunstall, J. (ed) Media occupations and professions. A reader Oxford: Oxford University Press. pp 1- 22.

Ursell, G. (1998) Labour flexibility in the UK commercial television sector. Media, culture and society 20 (1) 129 - 53.

Ursell, G. (2000) Television production: issues of exploitation, commodification and subjectivity in UK television labour markets. Media, culture and society 22 (6) $805-26$.

Ursell, G. (2003) Creating value and valuing creation in contemporary UK television: or 'dumbing down' the workforce. Journalism Studies 4 (1) pp31-46.

Waisbord, S. (2000) Watchdog journalism in South America: news, accountability, and democracy. New York: Columbia University Press.

Watkins, A. (2000) A short walk down Fleet Street. From Beaverbrook to Boycott. London, Duckworth. 
Weaver, D. (ed) (1998) The global journalist: news people around the world. London: Hampton Press.

Weaver, D. \& Wilhoit, G. C. (1996) The American journalist in the 1990s. US news people at the end of an era. Mahwah, NJ: Erlbaum.

Welch, M.R., Xu, Y., Bjarnason, T., Petee, T., O’Donnell, P. and Magro, P. (2005) 'But everybody does it...': The effects of perceptions, moral pressures, and informal sanctions on tax cheating. Sociological Spectrum 25. 21-52.

Wells, M. (2005) Have I got news for you. The Guardian 12 September.

Wells, M. and Ramesh, R. (2004) BBC reputation hit by Bhopal interview hoax The Guardian 4 December.

White, D.M. (1950) The gatekeeper: a case study in the selection of news. Journalism Quarterly 27, 383-90.

Younge, G. (2004) 'The man who took the New York Times for a ride’ The Guardian 6 March.

Zelizer, B. (2004) Taking journalism seriously. News and the academy. London: Sage Publications.

\footnotetext{
${ }^{1}$ I am very grateful to Anne Murcott for conversations when this article was at its formative stage and for subsequent suggestions. I must also thank the editors and the two anonymous reviewers for their very helpful comments.
}

${ }^{2}$ I am very grateful to Anne Murcott for conversations when this article was at its formative stage and for subsequent suggestions. I must also thank the editors and the two anonymous reviewers for their very helpful comments.

${ }^{3}$ For example, a BBC news reporter was misled by a hoax website into broadcasting a report on 4 December 2004 that Dow Chemical had announced compensation terms for victims of the 1984 Bhopal disaster. The error was widely reported in the British press at the time (e.g. Wells and Ramesh (2004)). 


\footnotetext{
${ }^{4}$ Some news organizations publish corrections as a matter of routine. Others may only publish corrections when directed to do so by regulatory bodies (see Note 15).
}

${ }^{5}$ The most widely reported recent example in the UK was the 'Gilligan affair' which led to the resignations of the BBC's director general, the chairman of the BBC board of governors and the BBC Radio 4 Today reporter Andrew Gilligan in 2004. See Dyke (2004) for a detailed account.

${ }^{6}$ The cases of Jayson Blair of the New York Times, (see Blair, 2004); Stephen Glass of the New Republic; and Thomas Hickey of the Chicago Tribune, are perhaps the most notorious. Each was discovered inventing or plagiarizing news stories. More tragic was the case of James Forlong, a British Sky News television reporter who committed suicide shortly after losing his job for fabricating a report during the Iraq war in 2003.

${ }^{7}$ One means of preventing mistakes - and thus avoiding discredit and potentially costly litigation - is to employ fact checkers. The practice seems to be rare outside the US magazine publishing industry. Tight costs and production schedules make fact checking impracticable in most news media.

8 "The danger with 24-hour news is that it becomes a rolling service of rumour and speculation." (Helen Boaden, director, BBC news and current affairs, quoted in Wells (2005)).

${ }^{9}$ Jayson Blair described himself as 'out of touch with reality' by the time of his discovery (Younge, 2004). In evidence to the Hutton Inquiry, Andrew Gilligan was described as having a 'loose and in some ways distant relationship’ with the newsroom he was working for (Hutton, 2004 para 291).

${ }^{10}$ Dingwall (1976) explored the training of health visitors and role acquisition. This, he argues, entails a process of occupational accomplishment.

${ }^{11}$ Evidence from industrial sociology suggests that changes in the media industries are affecting employment practices in significant ways. Dex et al found a decline in salaried employment in the British television industry, freelance and fixed term contracts becoming more common, and job 
insecurity and uncertainty increasingly the norm. (Dex, et al 2000). Similar patterns have been found in British book publishing (Granger et al 1995), provincial newspapers and the magazine publishing industry (Gall 1998, 2002), television production (Ursell 1998, 2000,), and the film industry (Blair \& Rainnie, 2000, Blair, 2001). While this change can be understood in terms of wider industrial processes, this literature has so far dealt incompletely with the day-to-day activities and experiences of media workers themselves.

${ }^{12}$ The notion of 'occupation' is helpful for the analysis of an employment category whose members are more than three times more likely to think of themselves as belonging to a 'profession' than either a 'trade' or a 'craft' (Delano \& Henningham, 1995), although the fact that journalists continue to be divided over these terms attests to their increasing sense of uncertainty in changing times.

${ }^{13}$ But, as Freidson (1962) points out, professional status does not guarantee client confidence (p.214). The problem of public/client mistrust is characteristic of journalism. Considering professional conduct - and criticism of it - enriches our understanding of, for example, the reactions of both the BBC as an institution and $\mathrm{BBC}$ journalists as individual workers to the government questioning of their impartiality in the BBC's coverage of the Iraq War. Indignation was felt amongst journalists outside the BBC as well as inside: the National Union of Journalists responded with a series of public demonstrations protesting against the threat to 'journalistic independence.' These reactions can be understood as expressions of the claim to professional autonomy and self-regulation.

${ }^{14}$ The parallels with journalists as a group are striking. The Hutton Inquiry showed that the BBC's problems with its news supplier client (the government) threatened its standing with its news consuming client (its audience).

${ }^{15}$ In Freidson's study, professional etiquette, discretion, and doctors' loyalty to one another proved to be rather more powerful in controlling work than formal regulation. The enquiry into Dr Harold Shipman found that the tendency endures in the British medical profession, identifying "a culture within the GMC, a set of attitudes and an approach that put what was seen as being 'fair to doctors' ahead of protecting patients.” (Smith, J (2004) para 27.285, p1169)). 
${ }^{16}$ There is some debate over the way mistakes in the press are dealt with in the UK, although this tends to be confined to the pages of the left-liberal press. A minority of national newspapers - The Guardian, The Observer, The Independent, The Sunday Independent, - have full-time ombudsmen or women, leading a campaign for the widespread adoption of mechanisms for correcting mistakes and inaccuracies. There is also debate about the adequacy of the UK’s Press Complaints Commission's role as an instrument of self-regulation (Curran \& Seaton, 1997; O’Malley \& Soley, 1998). 